\title{
Potensi Pengembangan Kehutanan dan Pertanian Kabupaten Mahakam Ulu, Provinsi Kalimantan Timur
}

\author{
Forestry and Agriculture Development Potential of Mahakam Ulu Regency, \\ East Kalimantan Province
}

\begin{abstract}
Omo Rusdiana ${ }^{1}$, Supijatno $^{2}$, Yanto Ardiyanto $^{1}$ \& Candraningratri Ekaputri Widodo ${ }^{1^{*}}$
${ }^{1}$ Program Ekonomi dan Tata Ruang Wilayah, Pusat Pengkajian Perencanaan dan Pengembangan Wilayah (P4W) LPPM - Insititut Pertanian Bogor, Jl. Raya Pajajaran, Kampus IPB Baranangsiang, Bogor 16127;

${ }^{2}$ Departemen Agronomi dan Hortikultura, Fakultas Pertanian, Insititut Pertanian Bogor, Jalan Meranti, Kampus IPB Dramaga, Bogor 16680.*Penulis korespondensi.e-mail: candraningratri.widodo@gmail.com
\end{abstract}

(Diterima: 24 Oktober 2016; Disetujui: 3 Mei 2017)

\begin{abstract}
Mahakam Ulu Regency is a new autonomous region formed separated from Kutai Barat regency of East Kalimantan Province in 2013. The local government of Mahakam Ulu has set to develop their local economy by utilizing and developing local resources. The regency's geographical position at the northern border of Indonesia, together with its majority land coverage of natural forests, urges Mahakam Ulu to define its potential economic activities that support its people's welfare and preserve its nature at the same time. This research aims to understand the regional development potential of Mahakam Ulu Regency on the forestry and agriculture sector, as well as to define strategies for development. Competitive commodities analysis, land suitability analysis and land availability analysis for the competitive commodities were conducted to obtain accurate information on the region's forestry and agriculture potential. Analysis shows that Mahakam Ulu regency has forestry potentials in the form of development of community forest with non-timber forest products (NTFP) as the main commodity, environment service business in the form of ecotourism, utilization of timber forest products and NTFP, as well as development of customary forests. On the other side, potential agricultural commodities in Mahakam Ulu regency covers paddy, rubber, cacao and oil palm.
\end{abstract}

Keywords: agriculture, development strategies, forestry, land availability, Mahakam Ulu.

\begin{abstract}
ABSTRAK
Kabupaten Mahakam Ulu merupakan Daerah Otonomi Baru (DOB) hasil pemekaran dari Kabupaten Kutai Barat, Provinsi Kalimantan Timur. Pemerintah Kabupaten Mahakam Ulu telah menetapkan untuk memanfaatkan dan mengembangkan potensi ekonomi daerah sesuai sumber daya alam yang dimiliki. Letak geografis daerah yang terletak di kawasan perbatasan utara Pulau Kalimantan ditambah tutupan lahan yang sebagian besar merupakan hutan menjadikan Kabupaten Mahakam Ulu perlu mendefinisikan kegiatan ekonomi yang dapat dijadikan unggulan daerah, tidak saja yang mampu mendukung upaya peningkatan kesejahteraan masyarakat, namun juga sekaligus mampu menjaga kelestarian alamnya. Studi ini bertujuan memahami potensi wilayah yang dimiliki Kabupaten Mahakam Ulu pada subsektor kehutanan dan pertanian dan merumuskan strategi pengembangannya. Analisis komoditas unggulan, kesesuaian lahan, serta analisis ketersediaan lahan untuk komoditas unggulan dilakukan untuk mendapatkan informasi akurat terkait potensi pengembangan kehutanan dan pertanian daerah, untuk kemudian dirumuskan strategi
\end{abstract}


pengembangan yang sesuai. Hasil analisis menunjukkan bahwa potensi kehutanan di Kabupaten Mahakam Ulu meliputi pengembangan pola hutan kemasyarakatan dengan komoditas utama hasil hutan bukan kayu, usaha jasa lingkungan berupa ekowisata, usaha pemanfaatan hasil hutan kayu, dan hasil hutan bukan kayu melalui Izin Usaha Pemanfaatan Hasil Hutan Kayu (IUPHHK) - Hutan Alam, IUPHHK - Hutan Tanaman dan Izin Usaha Pemanfaatan Hasil Hutan Bukan Kayu (IUPHHBK), serta pengembangan hutan adat. Sementara itu, komoditas pertanian yang potensial dikembangkan meliputi padi sawah, padi ladang, karet, kakao, dan kelapa sawit.

Kata kunci: kehutanan, ketersediaan lahan, Mahakam Ulu, pertanian, strategi pengembangan.

\section{PENDAHULUAN}

Kabupaten Mahakam Ulu merupakan Daerah Otonomi Baru (DOB) hasil pemekaran Kabupaten Kutai Barat, Provinsi Kalimantan Timur, yang ditetapkan melalui UndangUndang Nomor 2 Tahun 2013 tentang Pembentukan Kabupaten Mahakam Ulu di Provinsi Kalimantan Timur. Kabupaten Mahakam Ulu terletak di wilayah perbatasan utara Kalimantan yang berbatasan langsung dengan negara bagian Serawak, Malaysia Timur. Kabupaten Mahakam Ulu dibentuk sebagai solusi optimalisasi pelayanan publik melalui perpendekan rentang kendali (span of control) pemerintahan agar lebih efisien dan efektif sejalan dengan prinsip-prinsip tata kelola pemerintahan yang baik (good governance) guna mempercepat terwujudnya kesejahteraan masyarakat, memperkuat daya saing daerah dan memperkokoh keutuhan Negara Kesatuan Republik Indonesia (NKRI) di wilayah perbatasan dengan negara tetangga. Dengan luasnya wilayah kabupaten induk Kutai Barat, letak geografis yang strategis, serta terbatasnya anggaran pembangunan di wilayah perbatasan, maka pemekaran merupakan salah satu upaya dalam menata wilayah yang berbatasan langsung dengan negara tetangga, dimana aktivitas illegal logging, human trafficking, penyeludupan obat-obatan terlarang dan pencaplokan wilayah merupakan hal yang rawan.

Dalam melaksanakan otonomi daerah, Kabupaten Mahakam Ulu perlu melakukan berbagai upaya peningkatan kemampuan ekonomi, penyiapan sarana dan prasarana, pemberdayaan dan peningkatan kualitas sumber daya manusia, serta pengelolaan sumber daya alam sejalan dengan peraturan perundangan. Pemerintah Kabupaten Mahakam Ulu telah menetapkan untuk memanfaatkan dan mengembangkan potensi ekonomi daerah sesuai sumber daya alam yang dimiliki. Letak geografis daerah yang terletak di kawasan perbatasan Utara Kalimantan, ditambah tutupan lahan yang sebagian besar merupakan kawasan hutan, menjadikan Kabupaten Mahakam Ulu perlu mendefinisikan kegiatan ekonomi yang dapat dijadikan unggulan daerah dan mendukung upaya peningkatan kesejahteraan masyarakat. Studi ini bertujuan:

1) Mengindentifikasi potensi kehutanan dan pertanian Kabupaten Mahakam Ulu, yang merupakan dua aset dan potensi utama Kabupaten Mahakam Ulu;

2) Menyusun rekomendasi upaya-upaya yang perlu dilakukan oleh Pemerintah Daerah Kabupaten Mahakam Ulu melalui strategi pengembangan wilayah.

\section{METODOLOGI}

Pendekatan yang dilakukan dalam studi potensi pengembangan kehutanan dan pertanian di Kabupaten Mahakam Ulu berorientasi pada pemanfaatan sumber daya dengan tetap memperhatikan daya dukung lingkungan dan proses yang partisipatif. Penekanan pada subsektor kehutanan dan pertanian dilakukan dengan mempertimbangkan kondisi eksisting Kabupaten Mahakam Ulu, ketika lebih 90\% merupakan lahan hutan dan pertanian lahan kering, merupakan aset yang penting 
dilestarikan dan dikembangkan secara berkelanjutan.

Studi ini diawali dengan pengumpulan data, baik data sekunder maupun data primer, untuk mendapatkan gambaran umum terkait kondisi aktual kabupaten, serta isu-isu pengembangan kehutanan dan pertanian di Kabupaten Mahakam Ulu. Data sekunder bersumber dari publikasi Kabupaten Mahakam Ulu, Kabupaten Kutai Barat selaku kabupaten induk dan Provinsi Kalimantan Timur terkait kebijakan pembangunan, kondisi sosial ekonomi, sumber daya alam, sumberdaya buatan, sumber daya manusia, penggunaan lahan, kelembagaan dan lain-lain. Data primer dikumpulkan melalui survei lapangan yang meliputi observasi fisik, diskusi dengan instansi terkait dan wawancara dengan masyarakat.

Metode yang digunakan dalam studi ini meliputi analisis deskriptif dan analisis data. (1) analisis deskriptif potensi kehutanan dan pertanian; dan (2) analisis deskriptif arah pengembangan kehutanan dan pertanian. Analisis deskriptif potensi kehutanan dan pertanian dilakukan berdasarkan pertimbangan ketersediaan dan kesesuaian lahan, komoditas unggulan, serta permasalahan yang dihadapi. Sedangkan analisis deskriptif arahan pengembangan kehutanan dan pertanian memperhatikan fungsi kawasan, prospek pasar, ketersediaan lahan, minat masyarakat serta penguasaan teknik budi daya.

Adapun analisis data yang dilakukan antara lain analisis penentuan komoditas unggulan, analisis kesesuaian lahan, analisis ketersediaan lahan, dan observasi lapangan untuk verifikasi kesesuaian lahan.

\section{Metode Analisis Penentuan Komoditas Unggulan}

Dalam pengembangan suatu komoditas, diperlukan beberapa persyaratan, di antaranya kesesuaian serta ketersediaan lahan untuk pengembangan komoditas, kondisi agroklimat, tenaga kerja, sarana prasarana, serta kondisi sosial ekonomi budaya masyarakat (Babaloa et. al., 2011 dalam Setyawati, 2016). Suatu komoditas dapat dinyatakan sebagai komoditas unggulan jika merupakan komoditas andalan yang strategis untuk dikembangkan di suatu wilayah, memiliki keunggulan kompetitif dan memenuhi kriteria pengembangan komoditas sebagaimana disebutkan di atas.

Komoditas unggulan pertanian dalam studi ini ditentukan dengan cara pengamatan kondisi eksisting di lapangan (meliputi jenis komoditas, pertumbuhan luas lahan komoditas, pertumbuhan jumlah produksi komoditas, serta kondisi sosial ekonomi dan kelembagaan masyarakat) dan pencermatan kebijakan pengembangan pertanian Dinas Pertanian Kabupaten induk Kutai Barat.

\section{Metode Analisis Kesesuaian Lahan}

Prinsip dari analisis kesesuaian lahan adalah untuk memprediksi potensi dan keterbatasan lahan untuk produksi suatu komoditas (Ranya et al. 2013). Evaluasi kesesuaian lahan dilakukan dengan menggunakan metode FAO (Organisasi Pangan dan Pertanian Perserikatan Bangsa-Bangsa atau Food and Agriculture Association of the United Nations) yang dirumuskan tahun 1976 dan dimodifikasi oleh Balai Besar Sumber Daya Lahan Nasional, Kementerian Pertanian. Metode ini membandingkan karakteristik lahan/kualitas lahan dengan dengan kriteria kesesuaian lahan.

Sistem lahan dapat digunakan sebagai sistem informasi kualitas lahan dan evaluasi penggunaan lahan (Mahl, 1995 dan Syam et al., 1995 dalam Taiyeb, 2007; Kusumawati, 1997). Pengelompokan sistem lahan bertumpu pada informasi litologi dan landform yang sama pada masing-masing satuan fisiografi dan dibagi menjadi beberapa satuan lahan yang lebih kecil. Sistem lahan dipublikasi oleh RePPProt (Regional Physical Planning Programme for Transmigration) pada tahun 1988. Pendekatan sistem lahan mengelompokkan satu jenis tanah atau beberapa jenis tanah. Selanjutnya, zona agroklimat pada masing-masing sistem lahan dibagi menjadi satuan-satuan lahan yang lebih kecil yang disebut kompleks lahan yang didasarkan atas kesamaan jenis tanah dan zona 
agroklimat. Informasi kesesuaian lahan yang digunakan dari data sistem lahan adalah pertanian lahan basah, pertanian lahan kering, karet, kopi robusta, kelapa, kakao, cengkeh, lada, jambu mete dan kelapa sawit. Kesesuaian lahan untuk suatu komoditas dibedakan atas sesuai (S) dan tidak sesuai $(\mathrm{N})$.

Data hasil survei lapang sebagai input dalam analisis dikelompokkan ke dalam tipe penggunaan lahan (Land Utilization Type = LUT), persyaratan penggunaan lahan (Land Use Requirement $=$ LUR $)$, karakteristik lahan $($ Land Characteristic $=$ LC). Selanjutnya, ketika hasil evaluasi kesesuaian lahan (melalui Decision Tree $=$ DT $)$ menunjukkan sesuai untuk suatu komoditas unggulan, data tingkat pengelolaan komoditas $($ Commodity Management $=\mathrm{CM}$ ) akan ditambahkan untuk masukan analisis. Hasil analisis adalah daftar jenis serta kesesuaian lahan untuk komoditas unggulan dan potensial diunggulkan di tiap satuan peta lahan.

Hasil analisis kesesuaian lahan dengan program ArcGIS selanjutnya dijadikan input penyusunan peta sebaran spasial kesesuaian lahan. Peta sebaran kesesuaian lahan masingmasing komoditas ini bermanfaat untuk mengetahui sebaran areal yang dapat dikembangkan sehingga dapat menghasilkan produktivitas komoditas yang optimal.

\section{Kualitas lahan dan tanaman}

\section{Karakteristik Lahan}
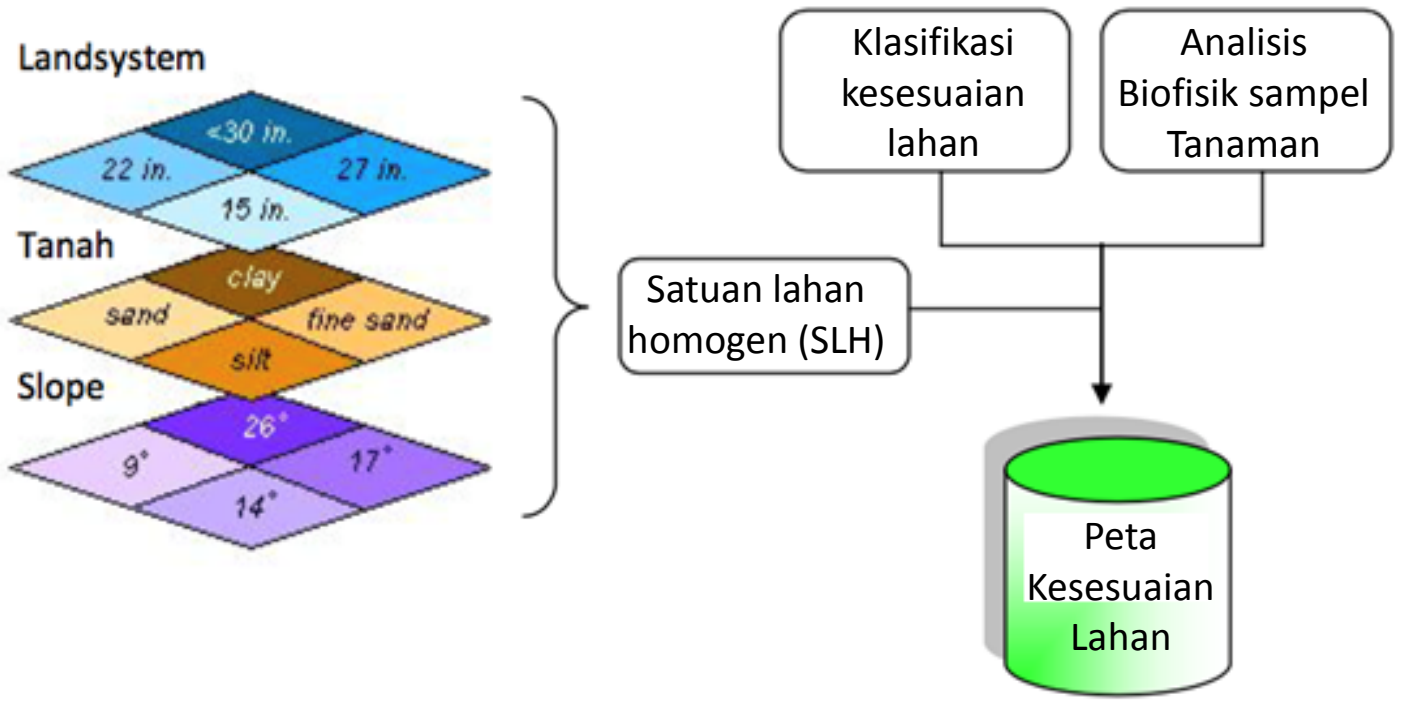

Gambar 1. Tahapan analisis evaluasi kesesuaian lahan Sumber: Studi P4W-LPPM IPB, 2011

\section{Metode Analisis Ketersediaan Lahan}

Selain kesesuaian lahan untuk komoditas, perlu dikaji pula ketersediaan lahan (land availability) terhadap komoditas tersebut. Kesesuaian lahan komoditas diperiksa terhadap aksesibilitasnya, yakni apakah berada di dalam kawasan yang boleh dikembangkan atau tidak, sehingga diperoleh ketersediaan lahan untuk pengembangan komoditas.

Kabupaten Mahakam Ulu sebagai daerah otonomi baru (DOB) belum memiliki Rencana
Tata Ruang Wilayah (RTRW) meskipun sebelumnya pernah berlaku RTRW kabupaten induk Kutai Barat. Dalam RTRW, pola ruang suatu daerah dibedakan atas kawasan lindung dan kawasan budi daya. Penentuan kawasan lindung di Kabupaten Mahakam Ulu didasarkan pada kriteria yang disajikan pada Tabel 1 berikut. Wilayah kabupaten yang tidak termasuk kawasan lindung merupakan kawasan budi daya. 
Tabel 1. Kriteria analisis areal kawasan lindung

\begin{tabular}{cl}
\hline $\begin{array}{c}\text { Kriteria Kawasan } \\
\text { Lindung }\end{array}$ & \multicolumn{1}{c}{ Uraian } \\
\hline Kriteria 1 & $\begin{array}{l}\text { Kawasan yang mempunyai kelerengan, kepekaan jenis tanah, dan intensitas curah hujan } \\
\geq 175\end{array}$ \\
\hline Kriteria 2 & $\begin{array}{l}\text { Kawasan dengan kelerengan }>40 \% \text { dan atau }>15 \% \text { untuk tanah sangat peka erosi (regosol, } \\
\text { litosol, organosol, renzina) }\end{array}$ \\
\hline Kriteria 3 & Kawasan dengan ketinggian $\geq 2.000$ m dari permukaan laut \\
\hline Kriteria 4 & $\begin{array}{l}\text { Kawasan perlindungan setempat: } \\
\text { Daratan sepanjang tepian laut dengan jarak paling sedikit 100 m dari titik pasang air laut } \\
\text { tertinggi ke arah darat, 500 m dari tepi waduk atau danau, 200 m dari tepi mata air dan kiri } \\
\text { kanan sungai di daerah rawa, 100 m dari kiri kanan tepi sungai, 50 m dari kiri-kanan tepi } \\
\text { anak sungai, 2 kali kedalaman jurang dari tepi jurang; } \\
\text { Kawasan pantai berhutan bakau dengan koridor pantai selebar paling sedikit 130 kali rata- } \\
\text { rata perbedaan air pasang tertinggi dan terendah tahunan, diukur dari garis air surut } \\
\text { terendah ke arah darat }\end{array}$ \\
\hline Kriteria 5 & Kawasan hutan lindung dan penyangga (buffer zone) hutan lindung \\
\hline Kriteria 6 & Kawasan cagar budaya dan atau ilmu pengetahuan \\
\hline Kriteria 7 & Kawasan rawan terhadap bencana alam \\
\hline Kriteria 8 & Kemampuan dan kesesuaian lahan, serta pertimbangan teknis ilmiah \\
\hline
\end{tabular}

Sumber: Keppres No. 32 Tahun 1990

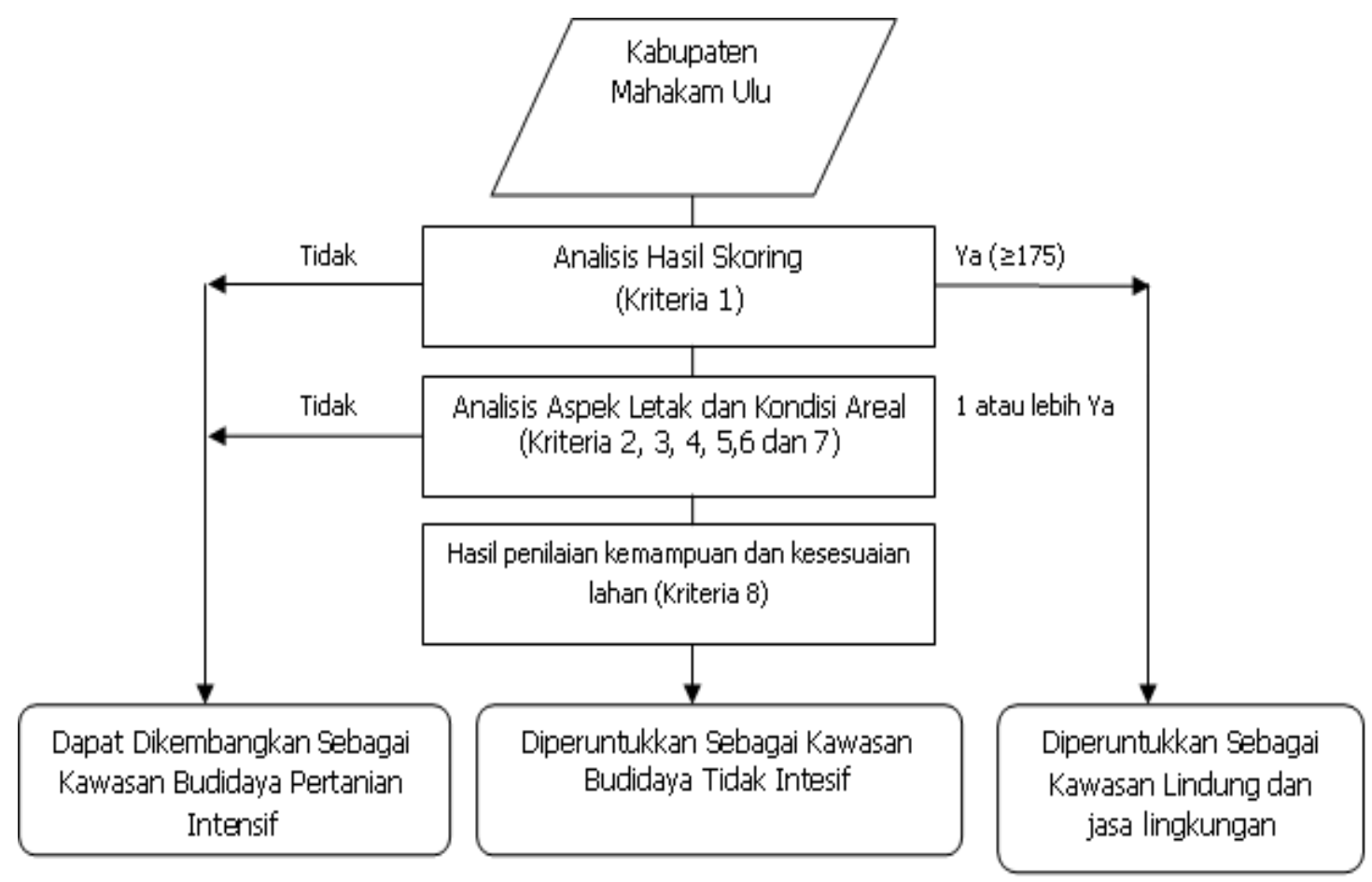

Gambar 2. Tahapan analisis penetapan kawasan lindung wilayah Sumber: Keputusan Presiden no. 32 Tahun 1990

Melalui metode analisis ketersediaan lahan ini dapat diketahui area mana saja di wilayah Kabupaten Mahakam Ulu yang sebaiknya diarahkan sebagai kawasan lindung dan jasa lingkungan, kawasan budi daya tidak intensif dan kawasan budi daya pertanian intensif. 


\section{HASIL DAN PEMBAHASAN}

\section{Keadaan Umum Wilayah Studi}

Letak Geografi dan Wilayah Administrasi

Kabupaten Mahakam Ulu terdiri atas lima kecamatan (Laham, Long Apari, Long Bagun, Long Hubung, Long Pahangai) yang terbagi menjadi 50 kampung/desa dengan wilayah keseluruhan $\pm 15,315 \mathrm{~km}^{2}$ (UU No. 2 tahun 2013). Luas wilayah Kabupaten Mahakam Ulu berdasarkan hitungan peta digital adalah $\pm 18,869 \mathrm{~km}^{2}$. Secara geografis kabupaten ini terletak antara $113^{\circ} 48^{\prime} 49^{\prime \prime}$ BT sampai $115^{\circ} 45^{\prime} 49^{\prime \prime}$ BT, serta antara $1^{0} 31^{\prime} 05^{\prime \prime}$ ' LU dan $0^{0} 9{ }^{\prime} 00$ " LS. Secara administratif Kabupaten Mahakam Ulu mempunyai batas-batas wilayah:

1) sebelah Utara: Kecamatan Kayan Selatan, Kabupaten Malinau, Provinsi Kalimantan Utara, dan negara bagian Sarawak, Malaysia;

2) sebelah Timur: Kecamatan Tabang, Kabupaten Kutai Kartanegara, Provinsi Kalimantan Timur;

3) sebelah Selatan: Kecamatan Long Iram dan Kecamatan Linggang Bigung, Kabupaten Kutai Barat, Provinsi Kalimantan Timur, serta Kecamatan Uut Murung dan Kecamatan Sumber Barito, Kabupaten Murung Raya, Provinsi Kalimantan Tengah;

4) sebelah Barat: Kecamatan Putussibau Utara, Kabupaten Kapuas Hulu, Provinsi Kalimantan Barat.

\section{Topografi dan Iklim}

Wilayah Kabupaten Mahakam Ulu tidak dilewati jalur gunung api, namun terdapat pegunungan di wilayah perbatasan Utara yang membujur dari Utara ke Selatan. Dengan kondisi topografi demikian, permukiman penduduk lebih banyak dijumpai di wilayah sepanjang sungai Mahakam yang datar. Kecamatan Long Bagun, Long Apari, dan Long Pahangai berada pada ketinggian lebih dari 100 $\mathrm{m}$ di atas permukaan laut (dpl), sedangkan kecamatan lainnya sebagian besar terletak di bawah $100 \mathrm{~m}$ dpl. Karakteristik iklim Kabupaten Mahakam Ulu termasuk dalam kategori iklim tropika humida dengan rata-rata curah hujan tertinggi pada bulan April dan terendah pada bulan Agustus. Dalam satu tahun selalu terdapat sekurang- kurangnya tujuh hari hujan, namun beberapa tahun terakhir iklim menjadi tidak menentu. Temperatur minimum umumnya terjadi pada bulan Oktober sampai dengan Januari sedangkan temperatur maksimum terjadi antara bulan Agustus sampai dengan bulan September. Iklim seperti ini menjadikan Kabupaten Mahkam Ulu tidak mempunyai perbedaan yang jelas antara musim hujan dan musim kemarau.

\section{Geologi dan Jenis Tanah}

Struktur geologi Provinsi Kalimantan Timur didominasi oleh batuan sedimen liat berlempung selain kandungan batuan endapan tersier dan batuan endapan kwarter. Formasi batuan endapan utama terdiri atas batuan pasir kwarsa dan batuan liat. Jenis tanah di sebagian besar daratan Kalimantan Timur didominasi oleh jenis tanah podsolik merah kuning dengan tingkat kesuburan relatif rendah. Jenis tanah di Kabupaten Mahakam Ulu terdiri atas podsolik, alluvial, gleisol, organosol, lithosol, latosol, andosol, regosol, renzina, dan mediteran, sesuai dengan kondisi iklim Kalimantan Timur yang tergolong ke dalam tipe iklim tropika humida yang bersifat masam. Tanah podsolik merupakan jenis tanah dengan areal terluas yang masih memungkinkan pengembangan areal pertanian. 


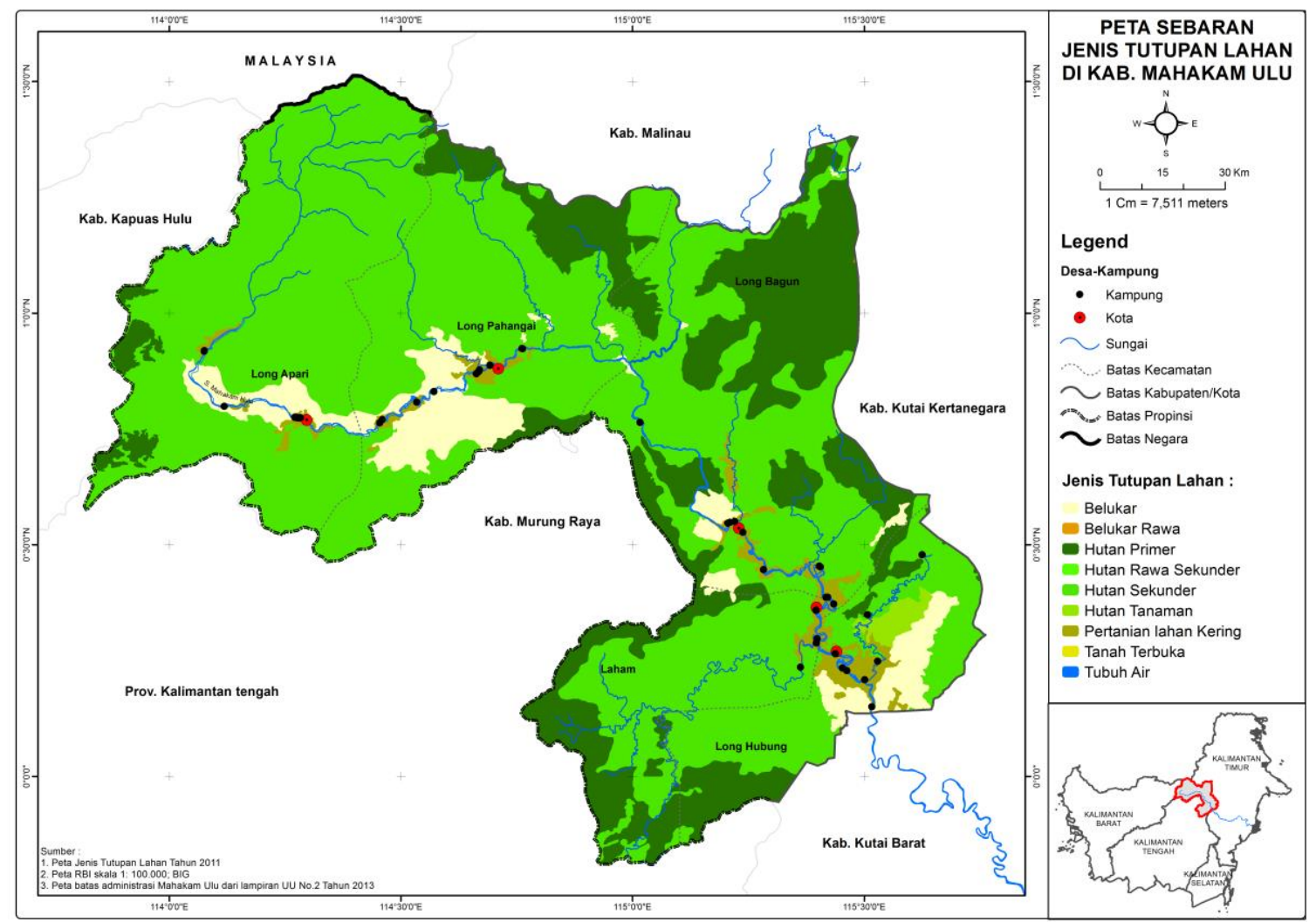

Gambar 3. Penutupan lahan Kabupaten Mahakam Ulu Sumber: Hasil analisis tim studi P4W-LPPM IPB, 2013

\section{Penutupan Lahan}

Kondisi penutupan lahan di Kabupaten Mahakam Ulu secara umum masih berupa vegetasi. Luasan hutan berkurang dalam jumlah besar dibandingkan dengan tiga dekade sebelumnya dikarenakan pembalakan liar.
Hutan-hutan yang belum mengalami kegiatan pembalakan hutan terletak di wilayah pegunungan atau sebelah utara. Hutan yang masih hijau termasuk dalam status hutan lindung. Di sisi lain, tutupan lahan berupa hutan sekunder dan semak belukar umumnya berada di hutan produksi.

Tabel 2. Luas Penutupan Lahan Kabupaten Mahakam Ulu Tahun 2010

\begin{tabular}{llccccccc}
\hline \multirow{2}{*}{ No } & $\begin{array}{c}\text { Jenis } \\
\text { Tutupan } \\
\text { Lahan }\end{array}$ & $\begin{array}{c}\text { Long } \\
\text { Hubung }\end{array}$ & Laham & $\begin{array}{c}\text { Long } \\
\text { Bagun }\end{array}$ & $\begin{array}{c}\text { Long } \\
\text { Pahangai }\end{array}$ & $\begin{array}{c}\text { Long } \\
\text { Apari }\end{array}$ & \multirow{2}{*}{ (ha) } & $(\%)$ \\
\hline 1 & Belukar & 32,401 & 738 & 14,332 & 60,955 & 26,658 & 135,086 & 7.17 \\
& & $14.71 \%$ & $0.32 \%$ & $2.82 \%$ & $14.01 \%$ & $5.42 \%$ & & \\
\hline 2 & Belukar Rawa & - & - & 97 & - & - & 97 & 0,01 \\
& & $0 \%$ & $0 \%$ & $0,02 \%$ & $0 \%$ & $0 \%$ & & \\
\hline 3 & Hutan Primer & 37,845 & 78,187 & 214,576 & 62,368 & 18,777 & 411,754 & 21.82 \\
& & $17.18 \%$ & $33.8 \%$ & $42.22 \%$ & $14.33 \%$ & $3.82 \%$ & & \\
\hline 4 & Hutan Rawa & - & - & 43 & - & - & 43 & 0 \\
& Sekunder & $0 \%$ & $0 \%$ & $0,01 \%$ & $0 \%$ & $0 \%$ & & \\
\hline 5 & Hutan & 120,859 & 147,725 & 261,388 & 301,636 & 439,051 & $1,270,659$ & 67.34 \\
& Sekunder & $54.88 \%$ & $63.86 \%$ & $51.43 \%$ & $69.33 \%$ & $89.22 \%$ & & \\
\hline 6 & Hutan & 11,110 & - & - & - & - & 11,110 & 0.59 \\
& Tanaman & & & & & & & \\
\hline
\end{tabular}


Tabel 2. (lanjutan)

\begin{tabular}{ccccccccc}
\hline \multirow{2}{*}{ No } & $\begin{array}{c}\text { Jenis } \\
\text { Tutupan } \\
\text { Lahan }\end{array}$ & $\begin{array}{c}\text { Long } \\
\text { Hubung }\end{array}$ & Laham & $\begin{array}{c}\text { Long } \\
\text { Bagun }\end{array}$ & $\begin{array}{c}\text { Long } \\
\text { Pahangai }\end{array}$ & $\begin{array}{c}\text { Long } \\
\text { Apari }\end{array}$ & \multirow{2}{*}{ (ha) } & (\%) \\
\hline 7 & Pertanian & 17,082 & 4,272 & 15,170 & 9,065 & 6,212 & 51,800 & 2.75 \\
& Lahan Kering & $7.76 \%$ & $1.85 \%$ & $2.98 \%$ & $2.08 \%$ & $1.26 \%$ & & 0 \\
\hline 8 & Tanah & 36 & 2 & - & - & - & 37 & \\
& Terbuka & & & & & & & \\
& & 0.02 & $0 \%$ & $0 \%$ & $0 \%$ & $0 \%$ & & 0.34 \\
\hline 9 & Tubuh Air & 891 & 388 & 2.602 & 1.078 & 1.379 & 6,338 & \\
& & $0.4 \%$ & $0.17 \%$ & $0.51 \%$ & $0.25 \%$ & $0.28 \%$ & & 100 \\
\hline
\end{tabular}

Sumber: Hasil analisis Tim Studi P4W-LPPM IPB, 2013

Demografi

Pada saat pembentukannya tahun 2012, jumlah penduduk Kabupaten Mahakam Ulu tercatat berjumlah $\pm 27,923$ jiwa (UU No. 2 tahun 2013). Jumlah tersebut mengalami penurunan menjadi 25,970 jiwa pada akhir tahun 2015 dengan kepadatan $1.69 \mathrm{jiwa} / \mathrm{km}^{2}$ dengan komposisi laki-laki $53.35 \%$ dan perempuan $46.65 \%$ (BPS Kabupaten Kutai Barat, 2016).

Tabel 3. Demografi Kabupaten Mahakam Ulu Tahun 2015

\begin{tabular}{|c|c|c|c|c|c|c|}
\hline Kecamatan & $\begin{array}{r}\text { Luas } \\
\left(\mathbf{k m}^{2}\right)\end{array}$ & $\begin{array}{c}\text { Jumlah } \\
\text { kampung/ } \\
\text { desa }\end{array}$ & $\begin{array}{c}\text { Rumah } \\
\text { Tangga } \\
\text { (RT) }\end{array}$ & $\begin{array}{c}\text { Jumlah } \\
\text { Penduduk } \\
\text { (jiwa) }\end{array}$ & $\begin{array}{c}\text { Kepadatan } \\
\left(\mathbf{R T} / \mathbf{k m}^{2}\right)\end{array}$ & $\begin{array}{l}\text { Kepadatan } \\
(\text { jiwa/ km²) }\end{array}$ \\
\hline Long Hubung & 530.90 & 11 & 1,815 & 6,675 & 3.42 & 12.57 \\
\hline Laham & 901.80 & 5 & 556 & 2,345 & 0.62 & 2.60 \\
\hline Long Bagun & $4,971.20$ & 11 & 2,049 & 8,178 & 0.41 & 1.65 \\
\hline Long Pahangai & $3,420.40$ & 13 & 1,181 & 4,528 & 0.35 & 1.32 \\
\hline Long Apari & $5,490.70$ & 10 & 990 & 4,244 & 0.18 & 0.77 \\
\hline Total & $15,315.00$ & 49 & 6,591 & 25,970 & 0.43 & 1.70 \\
\hline
\end{tabular}

Sumber: BPS Kabupaten Kutai Barat, 2016

\section{Potensi Sumberdaya Pertanian}

\section{Potensi Kehutanan}

Berdasarkan luas wilayah, lebih dari $80 \%$ luas wilayah Kabupaten Mahakam Ulu berupa kawasan hutan. Berdasarkan tipe ekosistemnya, sebagian besar termasuk dalam tipe ekosistem hutan hujan tropis. Berdasarkan proporsi luasan per kecamatan, kawasan hutan yang paling luas berada di Kecamatan Long Apari (91\%) dan Long Pahangai (88\%).

Tabel 4. Hasil identifikasi kondisi eksisting kehutanan di Kabupaten Mahakam Ulu

\begin{tabular}{ll}
\hline Kawasan Hutan & \multicolumn{1}{c}{ Identifikasi Kondisi Eksisting } \\
\hline $\begin{array}{l}\text { Hutan Lindung/ } \\
\text { Hutan Produksi }\end{array}$ & $\begin{array}{l}\text { Masyarakat belum mengetahui tata batas antara hutan lindung serta hutan produksi } \\
\text { dengan lahan masyarakat dan hutan adat }\end{array}$ \\
\hline Hutan Adat & $\begin{array}{l}\text { Wilayah hutan adat sudah ditetapkan pemerintah namun belum jelas tata batasnya. } \\
\text { Masyarakat pernah mengusulkan penentuan tata batas tapi belum ada tindak lanjut }\end{array}$ \\
\cline { 2 - 3 } & $\begin{array}{l}\text { Setiap kampung/desa memiliki wilayah hutan adat yang dikelola dan dimanfaatkan } \\
\text { sesuai peruntukan menurut hukum adat. }\end{array}$ \\
\hline Hasil Hutan & \multicolumn{1}{l}{$\begin{array}{l}\text { Pemanfaatan kayu oleh masyarakat sebatas untuk bahan bangunan warga dan } \\
\text { pembangunan infrastruktur di kampung (kebutuhan lokal) }\end{array}$} \\
\hline Kayu &
\end{tabular}


Tabel 4. (lanjutan)

\begin{tabular}{|c|c|}
\hline & Identifikasi Kondisi Eksisting \\
\hline \multicolumn{2}{|l|}{ Kawasan Hutan } \\
\hline Gaharu & $\begin{array}{l}\text { Masyarakat mencari kayu gaharu di hutan untuk dijual kepada penampung dan dibawa } \\
\text { ke Samarinda. Akibat eksploitasi yang terus menerus, kayu gaharu mulai langka dan } \\
\text { sulit ditemukan. }\end{array}$ \\
\hline Damar & $\begin{array}{l}\text { Damar banyak terdapat di hutan sekitar kampung dan dimanfaatkan masyarakat untuk } \\
\text { bahan dempul perahu. } \\
\text { Tidak ada pasar. }\end{array}$ \\
\hline Rotan & $\begin{array}{l}\text { Rotan dapat menjadi salah satu potensi hutan non kayu yang dikembangkan dan } \\
\text { dimanfaatkan masyarakat untuk peningkatan ekonomi karena banyak terdapat di sekitar } \\
\text { kampung dan di dalam hutan. Pemanfaatan rotan oleh masyarakat baru untuk } \\
\text { pembuatan kerajinanan anyaman dalam jumlah sedikit. } \\
\text { Persoalan yang dihadapi adalah tidak ada pasar yang dapat menampung hasil rotan, } \\
\text { akibat mahalnya biaya transportasi/biaya angkut, sehingga rotan tidak memiliki nilai } \\
\text { ekonomis, termasuk untuk pemasaran hasil kerajinan anyaman dari bahan rotan. }\end{array}$ \\
\hline Madu & $\begin{array}{l}\text { Madu banyak terdapat di sekitar kampung dan dalam hutan, terutama pada musim } \\
\text { tanaman berbunga. Madu dimanfaatkan masyarakat untuk konsumsi sendiri atau dijual } \\
\text { di sekitar kampung (kebutuhan lokal). }\end{array}$ \\
\hline $\begin{array}{l}\text { Sarang burung } \\
\text { walet }\end{array}$ & $\begin{array}{l}\text { Pada era tahun '90an sarang walet alam menjadi primadona perekonomian masyarakat } \\
\text { di semua kecamatan. Burung walet alam ini membuat sarang di gua-gua yang banyak } \\
\text { terdapat di sekitar perkampungan dan di dalam hutan. Seiring perjalanan waktu, akibat } \\
\text { eksploitasi yang kurang memperhatikan keberlanjutan populasi, sarang burung walet } \\
\text { alam menjadi habis. Saat ini hampir tidak ada masyarakat yang mengusahakan sarang } \\
\text { burung karena sedikitnya populasi burung walet dan rendahnya harga. }\end{array}$ \\
\hline Anggrek & $\begin{array}{l}\text { Banyak jenis anggrek yang terdapat di hutan namun belum dimanfaatkan. } \\
\text { Tidak ada tempat pemasaran. }\end{array}$ \\
\hline Lain-lain & $\begin{array}{l}\text { Hasil hutan lain yang juga banyak terdapat di hutan di antaranya buah-buahan, tanaman } \\
\text { obat, satwa langka dan tanaman langka }\end{array}$ \\
\hline
\end{tabular}

Sumber: Hasil observasi lapang tim studi P4W-LPPM IPB, 2013

Potensi sumber daya hutan di kecamatan Long Apari dan kecamatan Long Pahangai sangat besar, khususnya yang berkaitan dengan potensi jasa lingkungan dan hasil hutan bukan kayu. Hal ini disebabkan di antaranya karena kedua kecamatan tersebut terletak di paling hulu dengan topografi pegunungan di perbatasan utara, dimana banyak jeram, air terjun, gua yang berpotensi untuk pengembangan wisata alam. Hasil hutan bukan kayu yang berpotensi dikembangkan di antaranya rotan, madu, sarang burung walet, anggrek, serta tanaman obat.

Berdasarkan hasil observasi lapangan, tegakan hutan di hutan produksi didominasi oleh jenis meranti dan keruing.

Pemanfaatan kawasan hutan di Kabupaten Mahakam Ulu masih terbatas pada pengusahaan berupa izin usaha pemanfaatan hasil hutan kayu (IUPHHK) dan izin pinjam pakai kawasan hutan (IPPKH) untuk kegiatan di luar kehutanan.

O. Rusdiana, Supijatno,

Y. Ardiyanto \& C.E. Widodo
Tabel 5. Peluang pengembangan kehutanan Kabupaten Mahakam Ulu

\begin{tabular}{|c|c|}
\hline $\begin{array}{l}\text { Status } \\
\text { Hutan }\end{array}$ & Peluang Pengembangan \\
\hline $\begin{array}{l}\text { Hutan } \\
\text { Lindung }\end{array}$ & $\begin{array}{l}\text { Ekowisata; } \\
\text { Hasil Hutan Bukan Kayu; } \\
\text { Pengembangan jasa lingkungan; } \\
\text { Penangkaran flora dan fauna }\end{array}$ \\
\hline $\begin{array}{l}\text { Hutan } \\
\text { Produksi } \\
\text { (HPT dan HP) }\end{array}$ & $\begin{array}{l}\text { Peningkatan produksi melalui } \\
\text { intensifikasi, diversifikasi produk } \\
\text { dan manajemen; } \\
\text { Pemanfaatan ruang } \\
\text { (agrofrorestry); } \\
\text { Ekowisata; } \\
\text { Penangkaran flora dan fauna }\end{array}$ \\
\hline
\end{tabular}

Di samping pemanfaatan yang sudah ada berupa IUPHHK dan IPPKH, potensi bentang alam yang menarik sangat potensial untuk pengembangan jasa lingkungan lainnya, antara lain ekowisata dan pengembangan energi terbarukan seperti PLTA.

Menurut estimasi, potensi PLTA di Kabupaten Mahakam Ulu dapat mencapai sekitar 2,700 MW (Inglin, 2007). 


\section{Potensi Pertanian Tanaman Pangan}

Data BPS Kabupaten Kutai Barat menunjukkan bahwa areal tanam padi ladang pada tahun 2011 mencakup areal seluas 3,943 ha yang tersebar di seluruh kecamatan. Produksi padi ladang pada tahun yang sama sebesar 11,194 ton atau dengan produktivitas 28.5 kw/ha. Padi ladang terbanyak ditanam di Kecamatan Long Pahangai dan Kecamatan Long Bagun. Di sisi lain, pertanaman padi sawah pada tahun 2011 hanya terdapat di kecamatan Long Hubung dengan luas areal tanam 25 ha dengan produksi 99 ton dan produktivitas sebesar $39.7 \mathrm{kw} / \mathrm{ha}$.

Dalam perkembangannya, luas panen padi ladang Kabupaten Mahakam Ulu menurun hingga pada tahun 2014 mencapai 3,051 ha dengan produksi 9,730 ton dan produktivitas sebesar $31.89 \mathrm{kw} / \mathrm{ha}$. Di sisi lain tidak tercatat ada lahan dan produksi padi sawah selama tahun
2014. Kecamatan dengan potensi pertanian tanaman pangan tertinggi adalah Kecamatan Long Bagun, dimana luas panen untuk tanaman padi di kecamatan tersebut adalah sebesar 907 ha dan produksi tanaman padinya mampu mencapai 2,892 ton atau sekitar $29.73 \%$ dari total produksi tanaman padi di Kabupaten Mahakam Ulu.

Meskipun saat ini padi sawah belum banyak dikembangkan masyarakat, Kabupaten Mahakam Ulu memiliki potensi pengembangan padi sawah sebagai sumber tanaman pangan. Hal ini dikarenakan modal alam berupa sebaran curah hujan yang merata sepanjang tahun tanpa bulan kering dan sepuluh sungai besar yang tidak pernah mengalami kekeringan.

Hasil analisis potensi dan ketersediaan lahan untuk padi ladang dan padi sawah di Kabupaten Mahakam Ulu ditunjukkan dalam kedua tabel dan gambar berikut.

Tabel 6. Analisis potensi dan ketersediaan lahan untuk padi ladang di Kabupaten Mahakam Ulu tahun 2014

\begin{tabular}{lrrrrr}
\hline \multicolumn{1}{c}{ Kecamatan } & $\begin{array}{c}\text { Lahan } \\
\text { Tersedia (ha) }\end{array}$ & $\begin{array}{c}\text { Luas Panen } \\
\text { (ha) }\end{array}$ & Potensi (ha) & $\begin{array}{c}\text { Produktivitas } \\
\text { (kw/ha) }\end{array}$ & Produksi (ton) \\
\hline Long Hubung & $27,533.59$ & 464 & $27,069,59$ & 31.89 & $1,479.70$ \\
Laham & $25,219.44$ & 366 & $24,853.44$ & 31.89 & $1,167.17$ \\
Long Bagun & $26,991.26$ & 907 & $24,206.36$ & 31.89 & $2,892.42$ \\
Long Pahangai & $24,897.36$ & 691 & $1,624.27$ & 31.89 & $2,203.60$ \\
Long Apari & $2,247.27$ & 623 & $27,069.59$ & 31.89 & $1,986.75$ \\
\hline Total & $108,666.92$ & 3,051 & $108,663.87$ & 31.89 & 9,730 \\
\hline
\end{tabular}

Sumber: Hasil analisis tim studi P4W-LPPM IPB, 2011 diperbaharui dengan data BPS Kabupaten Kutai Barat, 2016.

Tabel 7. Analisis potensi dan ketersediaan lahan untuk padi sawah di Kabupaten Mahakam Ulu

\begin{tabular}{lrrrrc}
\hline \multicolumn{1}{c}{ Kecamatan } & \multicolumn{1}{c}{$\begin{array}{c}\text { Lahan } \\
\text { Tersedia (ha) }\end{array}$} & $\begin{array}{c}\text { Luas Panen } \\
\text { (ha) }\end{array}$ & Potensi (ha) & Produktivitas (kw/ha) & $\begin{array}{c}\text { Produksi } \\
\text { (ton) }\end{array}$ \\
\hline Long Hubung & $8,481.37$ & 0 & $8,481.37$ & 0 & 0 \\
Laham & 394.79 & 0 & 394.79 & 0 & 0 \\
Long Bagun & $4,541.19$ & 0 & $4,541.19$ & 0 & 0 \\
Long Pahangai & $3,944.41$ & 0 & $3,944.41$ & 0 & 0 \\
Long Apari & 0.05 & 0 & 0.05 & 0 & 0 \\
\hline Total & $17,361.81$ & 0 & $17,361.81$ & 0 & 0 \\
\hline
\end{tabular}

Sumber: Hasil analisis tim studi P4W-LPPM IPB, 2011 diperbaharui dengan data BPS Kabupaten Kutai Barat, 2016. 


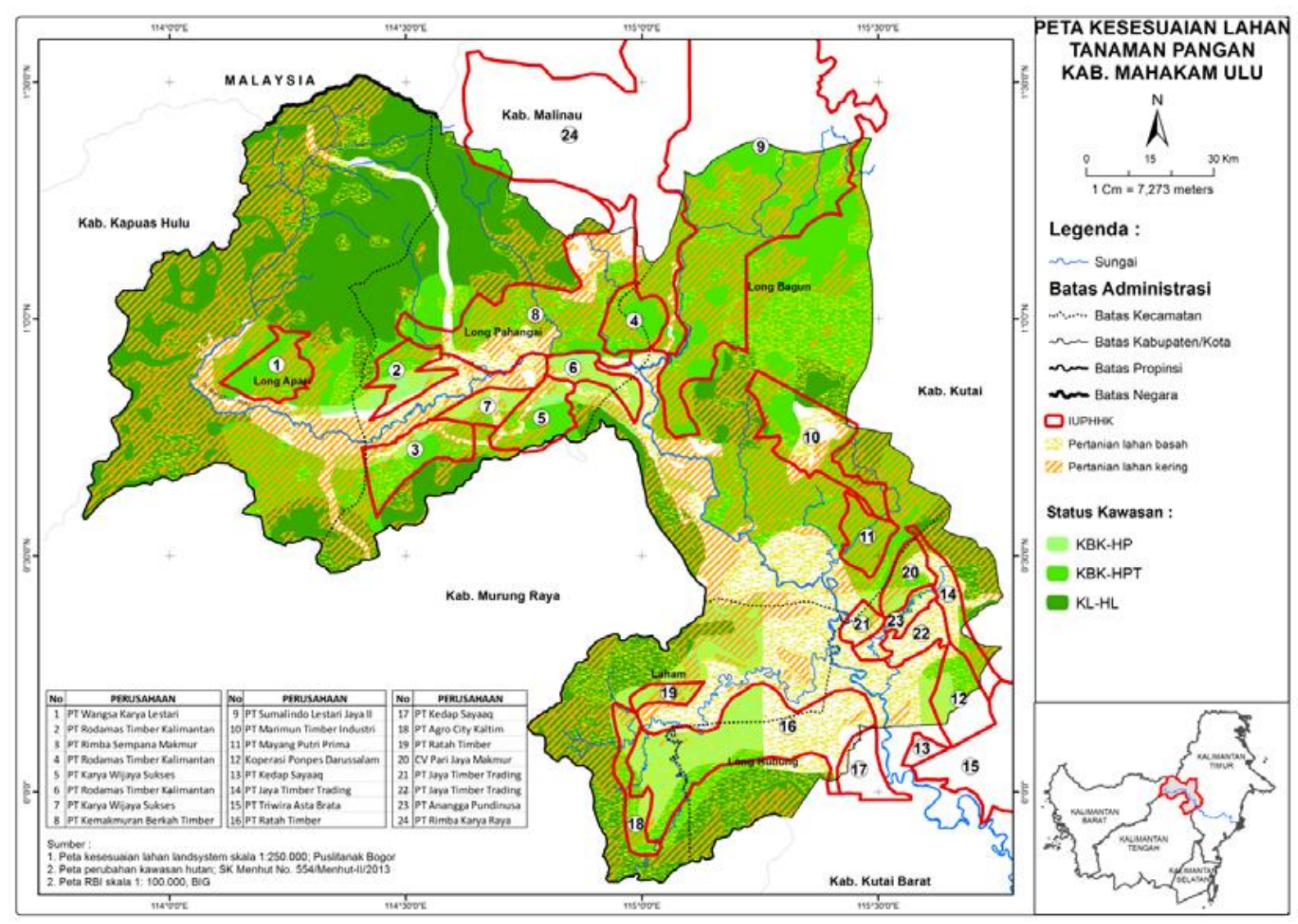

Gambar 4. Kesesuaian lahan untuk pertanian tanaman pangan (Padi Sawah dan Padi Ladang) di Kabupaten Mahakam Ulu

Sumber: Hasil analisis tim studi P4W-LPPM IPB, 2011

Upaya peningkatan produksi padi di Kabupaten Mahakam Ulu dapat dilakukan dengan mempertimbangkan daya dukung sumber daya lahan melalui peningkatan luas areal tanam serta peningkatan produktivitas dengan memanfaatkan inovasi teknologi budi daya padi ladang yang lebih baik serta perbaikan infrastruktur irigasi pada daerah yang dapat ditanami padi sawah. Produktivitas padi di Kabupaten Mahakam Ulu sudah cukup baik, namun usaha peningkatan produktivitas masih memungkinkan untuk dilakukan melalui: (a) pemanfaatan varietas padi gogo unggul baru serta varietas padi sawah unggul baru; (b) mempertahankan tingkat kesuburan tanah dengan memanfaatkan sisa bahan tanaman padi sebagai bahan organik; (c) mengurangi tingkat kehilangan hasil pascapanen; (d) pengendalian hama dan penyakit. Selain dari sisi teknis budi daya, peningkatan produksi juga harus diikuti oleh peningkatan peran lembaga sosial yang ada di masyarakat, peningkatan kualitas sumber daya manusia, dan pengembangan lembaga pemasaran yang dikelola secara baik dan efisien, serta pengembangan akses informasi terhadap perubahan dinamika pasar.

\section{Potensi Perkebunan}

Tanaman perkebunan yang terdapat di Kabupaten Mahakam Ulu antara lain karet, kakao, dan kelapa sawit.

a. Karet

Lahan perkebunan Kabupaten Mahakam Ulu sebagian besar dimanfaatkan untuk budi daya tanaman karet. Pada tahun 2012 luas areal perkebunan karet mencapai 1,549 ha dengan produksi 71.98 ton atau produktivitas $162.85 \mathrm{~kg} / \mathrm{ha}$. Tingkat produktivitas ini sangat jauh di bawah rata-rata tingkat produktivitas karet perkebunan rakyat nasional yang sudah mencapai lebih dari 900 kg/ha (Bappeda Kutai Barat, 2011). 
Luas areal perkebunan karet mengalami peningkatan hingga pada tahun 2014 tercatat Kabupaten Mahakam Ulu memiliki luas areal perkebunan karet seluas 1,705.5 ha atau sekitar $59,82 \%$ dari total luas areal tanaman perkebunan, dimana 557 ha di antaranya berada di Kecamatan Long Hubung Produksi karet menempati posisi paling tinggi, yakni sekitar $88.48 \%$ dari seluruh total produksi perkebunan atau merupakan komoditas perkebunan paling andalan Kabupaten Mahakam Ulu. Kecamatan dengan produksi karet tertinggi adalah Kecamatan Long Bagun yaitu sebesar 899.52 ton.

Tabel 8. Potensi dan analisis ketersediaan lahan perkebunan karet di Kabupaten Mahakam Ulu tahun 2014

\begin{tabular}{lrrrrrr}
\hline Kecamatan & $\begin{array}{c}\text { Lahan } \\
\text { Tersedia } \\
\text { (ha) }\end{array}$ & $\begin{array}{c}\text { Luas } \\
\text { Eksisting } \\
\text { (ha) }\end{array}$ & Potensi (ha) & $\begin{array}{c}\text { Produksi } \\
\text { (ton) }\end{array}$ & $\begin{array}{c}\text { Produktivitas } \\
\text { (kg/ha) }\end{array}$ & $\begin{array}{c}\text { Tenaga } \\
\text { Kerja } \\
\text { Perkebunan }\end{array}$ \\
\hline Long Hubung & $14,308.9$ & 557.00 & 13751.9 & 416.28 & $3,964.57$ & 605 \\
Laham & 903.1 & 67.00 & 836.1 & 29.12 & $2,426.67$ & 30 \\
Long Bagun & $28,408.3$ & 369.50 & 28038.8 & 899.52 & $3,527.53$ & 177 \\
Long Pahangai & $25,483.3$ & 527.00 & 24956.3 & 72.32 & $2,892.80$ & 226 \\
Long Apari & $2,306.8$ & 185.00 & 2121.8 & 120.12 & $2,669.33$ & 80 \\
\hline \multicolumn{1}{c}{ Total } & $71,410.4$ & $1,705.50$ & 28038.8 & $1,537.36$ & 3478.19 & 1,118 \\
\hline
\end{tabular}

Sumber: Hasil Analisis Tim Studi P4W-LPPM IPB, 2011 diperbaharui dengan data BPS Kabupaten Kutai Barat, 2016.

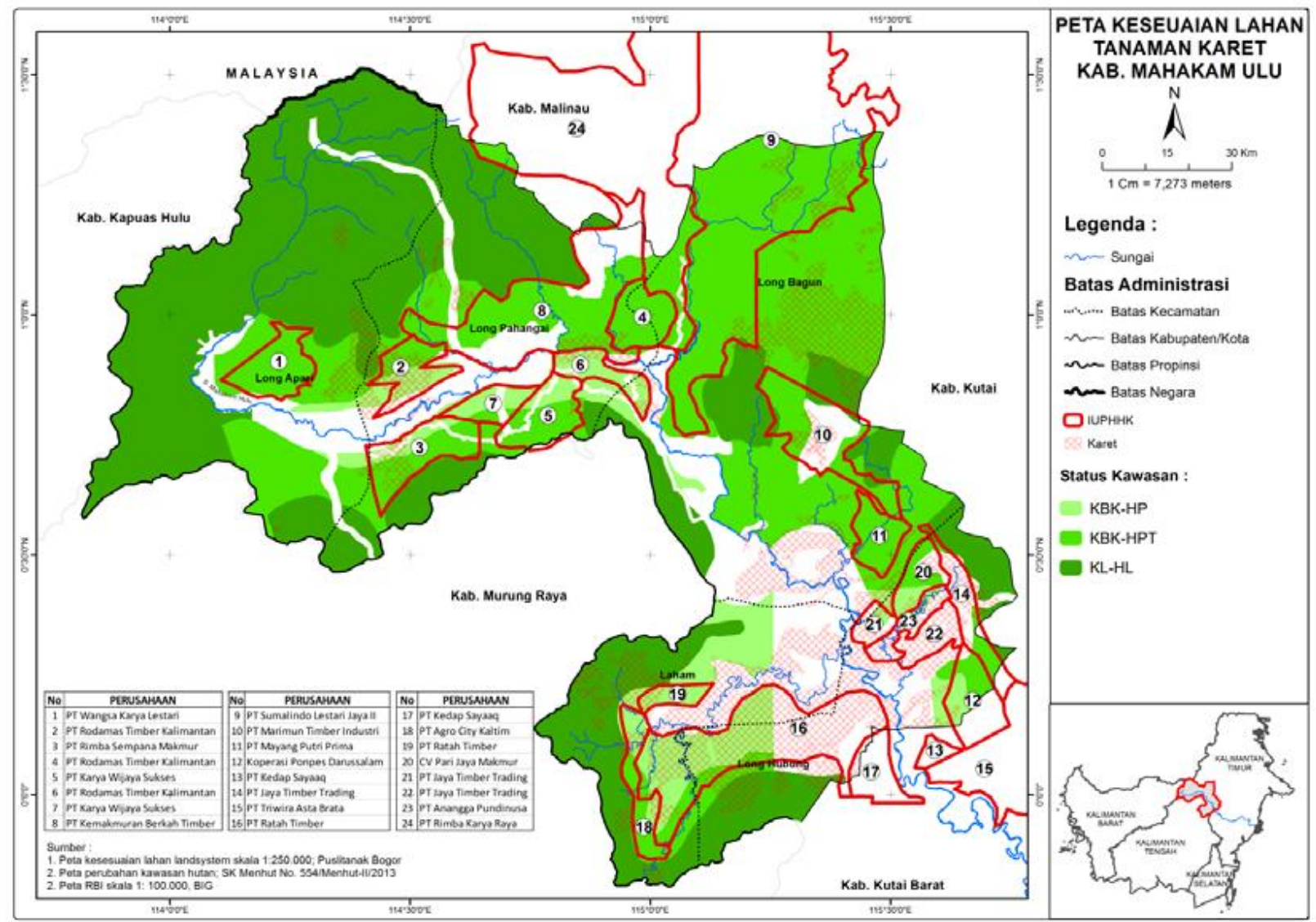

Gambar 5. Kesesuaian lahan untuk karet di Kabupaten Mahakam Ulu Sumber: Hasil Analisis Tim Studi P4W-LPPM IPB. 2011

Tingkat produktivitas yang dihasilkan masing-masing kecamatan sangat bervariasi. Hal ini menunjukkan bahwa tingkat penguasaan teknik budidaya dan panen tanaman karet ini bervariasi antar petani di kecamatan. Pada umumnya tanaman karet yang ada di masyarakat 
berasal dari benih yang tidak jelas mutunya atau benih lokal bermutu rendah sehingga potensi produksinya tidak dapat dijamin baik. Selain itu tanaman karet yang ada sudah tua dan tidak pernah dipelihara. Pola panen (interval sadap dan konsumsi kulit) juga belum dilakukan dengan baik sehingga kulit cepat habis dan produksi rendah karena terlalu sering disadap. Walaupun tanaman karet sudah dikenal lama oleh masyarakat, tetapi tampaknya pengetahuan teknis budi daya dan tata cara penyadapan karet masih merupakan hal yang sangat penting untuk diketahui oleh masyarakat.

Peningkatan produksi karet rakyat pada skala rumah tangga dan skala wilayah dapat dilakukan dengan perluasan kebun yang diusahakan oleh tiap pekebun, perluasan areal tanaman produktif dan peningkatan produktivitas. Nilai tambah produk karet dapat ditempuh dengan meningkatkan mutu lateks dan mengolahnya di dalam wilayah Kabupaten Mahakam Ulu.

\section{b. Kakao}

Tanaman perkebunan lain yang banyak diusahakan adalah kakao. Pada tahun 2011 luas areal tanaman kakao di kabupaten Mahakam Ulu mencapai 641 ha dengan produksi mencapai 53.55 ton biji kering atau produktivitasnya mencapai $345.89 \mathrm{~kg} / \mathrm{ha}$. Tingkat produktivitas kakao ini berada di bawah rata-rata produktivitas kakao nasional yang mencapai lebih dari $800 \mathrm{~kg} / \mathrm{ha}$ (Bappeda Kutai Barat, 2011). Tanaman kakao banyak ditemui di Kecamatan Long Pahangai dan Long Hubung, sedangkan tingkat produktivitas tertinggi terdapat di Kecamatan Long Bagun yaitu sebesar $623.13 \mathrm{~kg} / \mathrm{ha}$.

Pada tahun 2014, luas areal perkebunan kakao mengalami kenaikan menjadi 754.2 ha dengan produksi yang juga meningkat menjadi 64.45 ton biji kering. Namun di sisi lain, produktivitas tanaman kakao mengalami penurunan menjadi $218.47 \mathrm{~kg} / \mathrm{ha}$.

Tanaman kakao di Kabupaten Mahakam Ulu pada umumnya ditanam secara polikultur dengan tanaman keras lainnya seperti rambutan, durian atau tanaman kayu lainnya. Luas areal Tanaman Belum Menghasilkan (TBM) seluas 450 ha lebih luas dari luas areal Tanaman Menghasilkan (TM) seluas 295 ha menunjukkan bahwa banyak masyarakat yang mulai menanam kakao sebagai salah satu sumber pendapatan keluarga. Tingkat produktivitas yang masih rendah menunjukkan bahwa teknik budi daya kakao yang dilakukan oleh petani masih belum optimal. Oleh karena itu perlu adanya kegiatan pendampingan yang kontinyu agar kemampuan petani untuk mengelola tanaman kakao (pemeliharaan dan panen) dapat berkembang ke arah yang lebih baik. Sistem pengolahan biji kakao dan tata niaganya juga perlu mendapat perhatian agar petani mendapatkan posisi tawar yang lebih baik.

Tabel 9. Potensi perkebunan kakao di Kabupaten Mahakam Ulu tahun 2014

\begin{tabular}{|c|c|c|c|c|c|c|c|}
\hline \multirow[b]{2}{*}{ Kecamatan } & \multicolumn{4}{|c|}{ Luas Areal (ha) } & \multirow[b]{2}{*}{$\begin{array}{l}\text { Produksi } \\
\quad \text { (ton) }\end{array}$} & \multirow{2}{*}{$\begin{array}{l}\text { Produktivitas } \\
\text { (kg/ha) }\end{array}$} & \multirow{2}{*}{$\begin{array}{c}\text { Tenaga } \\
\text { Kerja } \\
\text { Perkebunan }\end{array}$} \\
\hline & TBM & TM & TT/TR & Jumlah & & & \\
\hline Long Hubung & 93.00 & 46.00 & 9.00 & 148.00 & 4.67 & 101.41 & 57 \\
\hline Laham & 42.00 & 24.20 & - & 66.20 & 11.41 & 471.61 & 33 \\
\hline Long Bagun & 25.00 & 15.00 & - & 40.00 & 9.36 & 624.13 & 8 \\
\hline Long Pahangai & 235.00 & 163.00 & - & 398.00 & 28.15 & 172.69 & 180 \\
\hline Long Apari & 55.00 & 46.80 & - & 102.00 & 10.86 & 232.05 & 47 \\
\hline Total & 450.00 & 295.00 & 9.00 & 754.20 & 64.45 & 218.47 & 325 \\
\hline
\end{tabular}

Sumber: BPS Kabupaten Kutai Barat, 2016.

\section{c. Kelapa Sawit}

Pengembangan perkebunan kelapa sawit di wilayah Kabupaten Mahakam Ulu hendaknya ditujukan sebesar-besarnya untuk meningkatkan pendapatan sebagian besar penduduk. Hal ini karena pengalaman Perkebunan Besar Swasta (PBS) kelapa sawit di wilayah Kutai Barat yang merupakan wilayah tetangga Mahakam Ulu 
tidak berdampak positif pada peningkatan pendapatan sebagian besar penduduk di sekitar kebun inti (Nasir et al., 2009). Penduduk di sekitar wilayah perkebunan kelapa sawit keterlibatannya masih terbatas hanya sebagai sumber tenaga kerja yang sebagian besar berstatus karyawan harian lepas (KHL). Sebagian besar penduduk tidak memiliki kebun kelapa sawit sebagai sumber pendapatan, baik yang berstatus kebun plasma maupun kebun rakyat swadaya.

Setelah diberikan HGU lahan kepada PBS kelapa sawit, penduduk sekitar tidak lagi memiliki akses untuk dapat mengusahakan lahan, kecuali pada lahan yang dialokasikan untuk kebun plasma yang proporsinya sedikit dan sampai saat ini pembangunannya lambat.

Tabel 10. Ketersediaan lahan untuk kelapa sawit di Kabupaten Mahakam Ulu

\begin{tabular}{|c|c|c|c|}
\hline Kecamatan & $\begin{array}{c}\text { Lahan } \\
\text { Tersedia } \\
\text { (ha) }\end{array}$ & $\begin{array}{c}\text { Luas } \\
\text { Eksisting } \\
\text { (ha) }\end{array}$ & $\begin{array}{c}\text { Potensi } \\
\text { (ha) }\end{array}$ \\
\hline Laham & $21,835.4$ & 0 & $21,835.4$ \\
\hline Long Apari & 0.0 & 0 & 0.0 \\
\hline Long Bagun & $8,967.8$ & 0 & $8,967.8$ \\
\hline $\begin{array}{l}\text { Long } \\
\text { Hubung }\end{array}$ & $14,356.5$ & 0 & $14,356.5$ \\
\hline $\begin{array}{l}\text { Long } \\
\text { Pahangai } \\
\end{array}$ & $4,085.2$ & 0 & $4,085.2$ \\
\hline Total & $49,244.9$ & 0 & $49,244.9$ \\
\hline
\end{tabular}

Sumber: Hasil analisis tim studi P4W-LPPM IPB. 2011

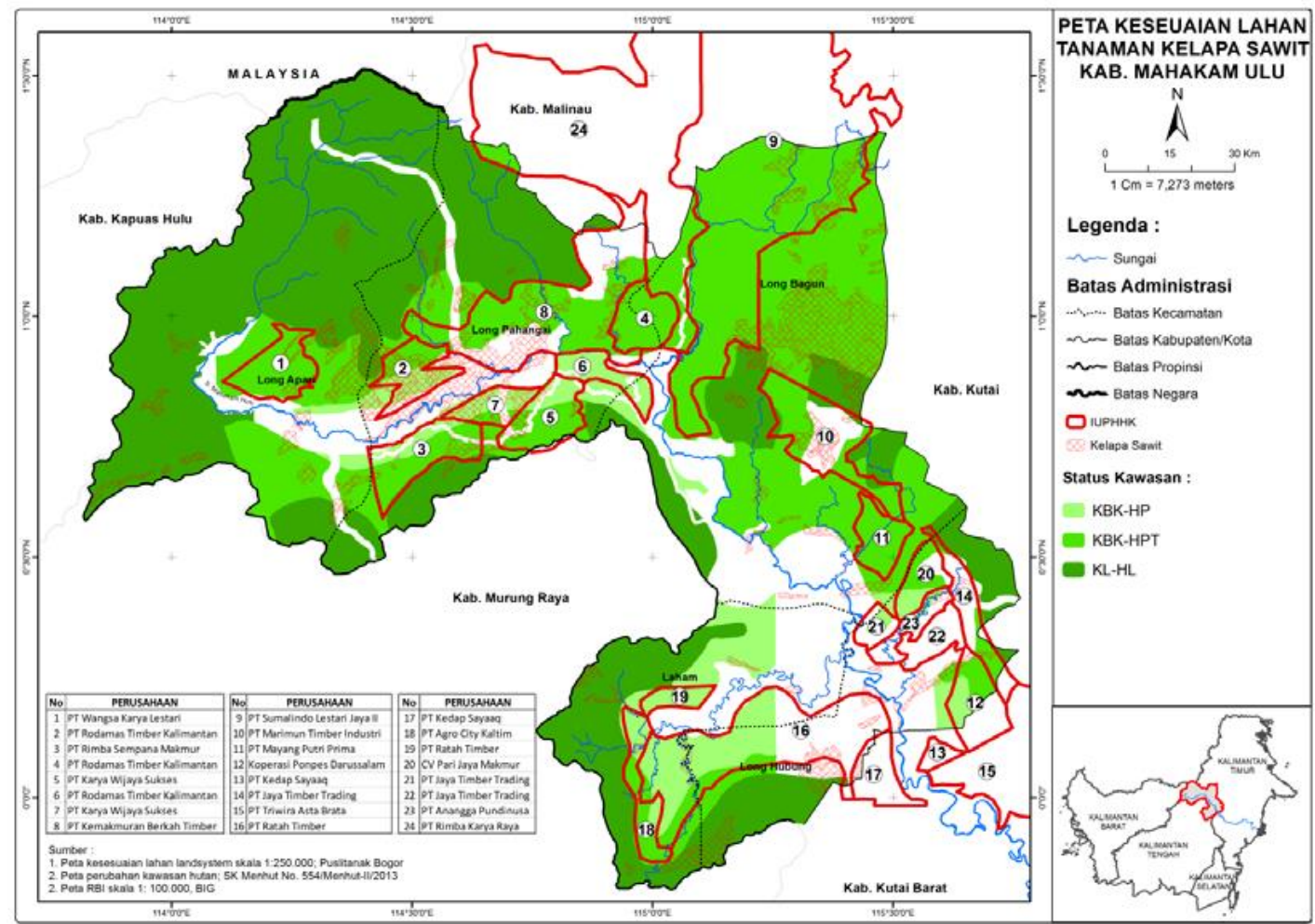

Gambar 6. Kesesuaian Lahan untuk Kelapa Sawit di Kabupaten Mahakam Ulu Sumber: Hasil Analisis Tim Studi P4W-LPPM IPB. 2011

\section{Arahan Pengembangan}

Arahan Pengembangan Sumber daya Kehutanan

Pengembangan sumber daya kehutanan sudah selayaknya berkelanjutan. Keberlanjutan di sektor kehutanan harus mencakup tiga elemen yang disarankan oleh Zonneveld (1990), yakni keberlanjutan ekonomi, keberlanjutan ekologi dan keberlanjutan sosio-politis, dan ditambah elemen keempat: keberlanjutan silvikultur. (Bowers, 2005).

Berdasarkan kesesuaian lahan, ketersediaan lahan, serta sosial budaya masyarakat, wilayah Kabupaten Mahakam Ulu 
dapat dikelompokkan dalam tiga zonasi wilayah yaitu: Kecamatan Long Apari dan Long Pahangai sebagai wilayah konservasi, jasa lingkungan dan hasil hutan bukan kayu; Kecamatan Long Bagun diprioritaskan untuk penghasil kayu alam, hasil hutan bukan kayu dan jasa lingkungan; serta Kecamatan Laham dan Long Hubung untuk pengembangan hutan tanaman dan hutan rakyat.

Tabel 11. Arah pengembangan sumber daya hutan di Kabupaten Mahakam Ulu

\begin{tabular}{|c|c|c|c|}
\hline $\begin{array}{l}\text { HL } \\
\text { (ha) }\end{array}$ & HP (ha) & HPT (ha) & Arah Pengembangan tiap Kecamatan \\
\hline \multicolumn{4}{|c|}{ Kecamatan Laham } \\
\hline 84,253 & 63,536 & 19,541 & \multirow{4}{*}{$\begin{array}{l}\text { Peningkatan produksi dengan intensifikasi, diversifikasi } \\
\text { produk dan manajemen; } \\
\text { Pemanfaatan ruang (HTR, agroforestry) } \\
\text { Pola pemanfaatan: HKm dan hutan desa, IUPHHK, } \\
\text { IUPHHBK }\end{array}$} \\
\hline \multirow[t]{3}{*}{$36.4 \%$} & $27.5 \%$ & $8.4 \%$ & \\
\hline & & & \\
\hline & & & \\
\hline \multicolumn{4}{|c|}{ Kecamatan Long Apari } \\
\hline 354,137 & 5,839 & 89,687 & \multirow{3}{*}{$\begin{array}{l}\text { Pemanfaatan ruang untuk berbagai kegiatan (eko-wisata, } \\
\text { karbon, HHBK) } \\
\text { Pengembangan jasa lingkungan, penangkaran flora-fauna } \\
\text { Pola pemanfaatan: HKm dan hutan desa }\end{array}$} \\
\hline $72 \%$ & $1.2 \%$ & $18.2 \%$ & \\
\hline & & & \\
\hline \multicolumn{4}{|c|}{ Kecamatan Long Bagun } \\
\hline 104,653 & 12,654 & 305,988 & \multirow{4}{*}{$\begin{array}{l}\text { Peningkatan produksi melalui intensifikasi, diversifikasi } \\
\text { produk dan manajemen } \\
\text { Pemanfaatan ruang (HTR, agroforestry) } \\
\text { Pengembangan jasa lingkungan Pola pemanfaatan: HKm } \\
\text { dan hutan desa, IUPHHK, IUPHHBK }\end{array}$} \\
\hline $20.6 \%$ & $2.5 \%$ & $60.2 \%$ & \\
\hline & & & \\
\hline & & & \\
\hline \multicolumn{4}{|c|}{ Kecamatan Long Hubung } \\
\hline 53,436 & 55,940 & 28,576 & \multirow{4}{*}{$\begin{array}{l}\text { Peningkatan produksi melalui intensifikasi, diversifikasi } \\
\text { produk dan manajemen } \\
\text { Pemanfaatan ruang (HTR, agroforestry) } \\
\text { Pola pemanfaatan: HKm dan hutan desa, IUPHHK, } \\
\text { IUPHHBK }\end{array}$} \\
\hline $24.3 \%$ & $25.4 \%$ & $13.0 \%$ & \\
\hline & & & \\
\hline & & & \\
\hline \multicolumn{4}{|c|}{ Kecamatan Long Pahangai } \\
\hline 173,488 & 49,509 & 160,298 & \multirow{3}{*}{$\begin{array}{l}\text { Pemanfaatan ruang untuk berbagai kegiatan (eko-wisata, } \\
\text { karbon, HHBK) } \\
\text { Pengembangan jasa lingkungan, penangkaran flora-fauna } \\
\text { Pola pemanfaatan: HKm dan hutan desa }\end{array}$} \\
\hline $39.9 \%$ & $11.4 \%$ & $36.8 \%$ & \\
\hline & & & \\
\hline
\end{tabular}

Berdasarkan fungsi hutan, bentukbentuk pengusahaan hutan yang potensial dikembangkan adalah sebagai berikut:

1) Hutan lindung dapat dikembangkan melalui pola Hutan Kemasyarakatan (HKm) dan Hutan Desa (HD) dengan komoditas utama Hasil Hutan Bukan Kayu (HHBK), usaha jasa lingkungan berupa ekowisata, air dan karbon. Dengan demikian izin usaha yang bisa dikembangkan adalah Izin Usaha Pemanfaatan Hasil Hutan Bukan Kayu (IUPHHBK) dan Izin Usaha Pemanfataan Jasa Lingkungan (IUP Jasling).
2) Hutan produksi dan hutan produksi terbatas: pola yang dapat dikembangkan adalah usaha pemanfaatan hasil hutan kayu dan hasil hutan bukan kayu melalui IUPHHK - Hutan Alam, IUPHHK - Hutan Tanaman dan IUPHHBK, hutan tanaman rakyat, hutan desa serta hutan kemasyarakatan.

3) Luar kawasan hutan (Area Penggunaan Lain/APL) dapat dikembangkan hutan rakyat dan hutan adat. 


\section{Arahan Pengembangan Sumber Daya Pertanian}

Rencana pengembangan suatu komoditas di suatu daerah didasarkan pada beberapa hal, seperti prospek pasar, kesesuaian lahan, ketersediaan lahan, minat masyarakat dan penguasaan teknik budi daya di suatu wilayah.

Tabel 12. Prioritas pengembangan komoditas di masing-masing kecamatan

\begin{tabular}{lcl}
\hline \multicolumn{1}{c}{ Kecamatan } & $\begin{array}{c}\text { Tanaman } \\
\text { Pangan }\end{array}$ & $\begin{array}{c}\text { Tanaman } \\
\text { Perkebunan }\end{array}$ \\
\hline Laham & Padi ladang & $\begin{array}{l}\text { Kakao, karet, } \\
\text { kelapa sawit }\end{array}$ \\
Long Apari & $\begin{array}{l}\text { Padi ladang, } \\
\text { padi sawah }\end{array}$ & Kakao, karet \\
Long Bagun & Padi ladang & $\begin{array}{l}\text { Kakao, karet, } \\
\text { kelapa sawit }\end{array}$ \\
Long Hubung & Padi ladang & $\begin{array}{l}\text { Kakao, karet, } \\
\text { kelapa sawit } \\
\text { Kakao, karet }\end{array}$ \\
\hline Long Pahangai & Padi ladang & \\
\hline
\end{tabular}

Dari Tabel 12 dapat dilihat bahwa kelima kecamatan di Kabupaten Mahakam Ulu memiliki prioritas pengembangan komoditas pertanian yang hampir sama. Padi ladang, kakao dan karet menjadi prioritas pengembangan di kelima kecamatan. Di sisi lain, padi sawah menjadi prioritas pengembangan hanya di kecamatan Long Apari.

Dalam rangka mendukung prioritas pengembangan komoditas di masing-masing kecamatan, diperlukan beberapa kegiatan pendukung berikut ini:

1) Pembangunan Jalan Usaha Tani. Pembangunan Jalan Usaha Tani (JUT) dilakukan untuk mendukung pembangunan pertanian. Dengan adanya pembangunan jalan ini diharapkan perluasan areal kebun, distribusi sarana produksi dan penjualan hasil panen dapat berjalan dengan lancar. Diperkirakan untuk 1 hektar lahan memerlukan jalan kebun sepanjang $10 \mathrm{~m}$.

2) Pembentukan dan peningkatan peran Kelompok Tani dan Koperasi Unit Desa (KUD).

Pembentukan kelompok tani dan KUD ini sangat penting untuk mendukung pembangunan pertanian dan distribusi sarana produksi agar menjadi lebih efisien dan efektif. Setiap 20-25 orang akan bergabung dalam satu kelompok tani. Sedangkan KUD dibentuk untuk membantu kelompok tani dalam mendapatkan sarana produksi dan pemasaran hasil pertanian.

3) Pelatihan penyegaran budi daya dan pasca panen kakao dan karet.

Pelatihan ini bertujuan menyegarkan kembali petani tentang budi daya kakao atau karet dengan memberikan informasi dan pelatihan teknik budi daya yang terbaru. Kedua komoditas ini sudah lama dikenal oleh petani, tetapi adanya perkembangan teknik budi daya dan cara panen yang baik perlu diinformasikan kepada petani. Setiap pelatihan dilaksanakan dalam dua hari dengan memberikan teori dan praktek percontohan teknik budi daya terbaru dan pasca panen yang baik dan benar.

4) Pendidikan dan Pelatihan Petugas Penyuluh Lapang (PPL) perkebunan

Untuk mendukung pengembangan perkebunan diperlukan tenaga penyuluh yang berperan sebagai fasilitator dan motivator bagi petani. Tenaga penyuluh ini diambil dari lulusan sekolah kejuruan pertanian yang selanjutnya dididik dan dilatih untuk menjadi seorang tenaga penyuluh lapang perkebunan. Pendidikan dan pelatihan ini dapat dilaksanakan di instansi terkait di Kabupaten Mahakam Ulu.

5) Pembinaan penangkar bibit tanaman perkebunan (kakao, karet dan kelapa sawit) Penyediaan bibit merupakan tahapan yang sangat penting dalam pengembangan perkebunan. Pada saat ini sudah terdapat penangkar-penangkar yang dibina oleh Dinas Perkebunan, tetapi jumlah yang ada saat ini dirasa masih kurang mendukung rencana pengembangan kebun di Kabupaten Mahakam Ulu. Oleh karena itu diperlukan penambahan jumlah penangkar bibit, selain untuk memenuhi kebutuhan bibit yang diperlukan juga penyebaran 
lokasi penangkaran sehingga memudahkan dalam distribusi bibit.

6) Pengadaan bibit kakao dan karet

Rencana pembangunan perkebunan di Kabupaten Mahakam Ulu memerlukan dukungan jumlah bibit yang cukup banyak. Satu hektar lahan memerlukan 1,000 bibit kakao, sedangkan untuk karet diperlukan bibit 500/hektar. Penyediaan bibit ini dapat dilakukan melalui penangkar-panangkar yang telah dibina oleh Dinas Perkebunan. Pemerintah Daerah membeli bibit dari lembaga penelitian untuk selanjutnya diperlihara dan diperbanyak oleh penangkar.

7) Pembangunan gudang penyimpanan sementara

Gudang penyimpanan sementara bertujuan penampungan sementara hasil kakao dan karet petani sebelum dijual ke pabrik. Gudang ini akan dikelola oleh KUD yang ada. Gudang dibuat dengan ukuran $5 \mathrm{~m} \mathrm{x} 4$ $m$ yang dapat menampung kurang lebih 10 ton lum atau lum mangkok.

8) Promosi investasi pembangunan pabrik karet

Seperti dikemukakan dalam analisis, potensi bahan baku karet yang ada di Kabupaten Mahakam Ulu cukup besar. Selama ini bahan baku tersebut diolah di pabrik pengolahan karet di Provinsi Kalimantan Timur. Oleh karena itu, Pemerintah Daerah perlu melakukan promosi kepada pihak swasta untuk berinvestasi pembangunan pabrik pengolahan karet di Kabupaten Mahakam Ulu. Diharapkan dengan promosi ini, ada pihak swasta yang berminat untuk membangun pabrik pengolahan karet.

9) Pembangunan pabrik pengolahan karet Pembangunan pabrik pengolahan karet ini akan dilakukan oleh pihak swasta. Pemerintah Daerah perlu memfasilitasi untuk mempermudah pemilihan lokasi, perizinan atau insentif lain yang dapat merangsang pihak swasta untuk berinvestasi. Lokasi pabrik diharapkan selain dapat menampung karet petani di sekitar lokasi pabrik, juga dapat mencegah larinya bahan baku karet untuk diolah di Kalimantan Timur.

\section{KESIMPULAN DAN REKOMENDASI}

Analisis potensi dan prospek pengembangan wilayah merupakan input penting bagi rencana-rencana pembangunan ke depan suatu DOB, yang kelak dituangkan ke dalam perencanaan spasial wilayah melalui Rencana Tata Ruang Wilayah (RTRW), Rencana Pembangunan Jangka Menengah Daerah (RPJMD) dan Rencana Pembangunan Jangka Panjang Daerah (RPJPD).

Kabupaten Mahakam Ulu sebagai DOB yang sebagian besar wilayahnya terdiri atas hutan memiliki banyak potensi pengembangan, khususnya potensi subsektor kehutanan dan pertanian. Potensi pengembangan kehutanan di Kabupaten Mahakam Ulu di antaranya adalah pengembangan pola hutan kemasyarakatan dengan komoditas utama hasil hutan bukan kayu, usaha jasa lingkungan berupa ekowisata, usaha pemanfaatan hasil hutan kayu dan hasil hutan bukan kayu melalui IUPHHK-hutan alam, IUPHHK-hutan tanaman dan IUPHHBK, serta pengembangan hutan adat. Sementara itu, komoditas pertanian yang potensial dikembangkan meliputi padi sawah, padi ladang, karet, kakao, dan kelapa sawit.

\section{Ucapan Terima Kasih}

Kajian ini disarikan dari kegiatan kerja sama antara Pusat Pengkajian Perencanaan dan Pengembangan Wilayah (P4W) Lembaga Penelitian dan Pengabdian kepada Masyarakat Institut Pertanian Bogor (LPPM-IPB) dengan Badan Perencanaan Pembangunan Daerah (Bappeda) Kabupaten Mahakam Ulu pada tahun anggaran 2013 yang berjudul "Studi Potensi Pengembangan Wilayah Kabupaten Mahakam Ulu". 


\section{DAFTAR PUSTAKA}

Babalola, T.S., Oso, T., Fasina, A.S., \& Gondanu, K. (2011). Land Evaluation Studies of Two Wetland Soils in Nigeria. International Research Journal of Agriculture Science and Soils Science, 1 (6), 193-204.

Badan Perencanaan Pembangunan Daerah (Bappeda) Kabupaten Kutai Barat. (2011). Laporan Akhir Master Plan Pertanian dalam Arti Luas. Kutai Barat: Bappeda Kabupaten Kutai Barat.

Badan Perencanaan Pembangunan Daerah (Bappeda) Kabupaten Mahakam Ulu. (2013). Laporan Akhir Studi Potensi Pengembangan Kabupaten Mahakam Ulu. Kutai Barat: Bappeda Kabupaten Mahakam Ulu.

Bowers, J. (2005). Instrument Choice for Sustainable Development: An Application to the Forestry Sector. Forest Policy and Economics, 7 (1), 97-107.

Badan Pusat Statistik (BPS) Kabupaten Kutai Barat. (2013). Kutai Barat Dalam Angka 2013. Kutai Barat: BPS Kabupaten Kutai Barat.

Badan Pusat Statistik (BPS) Kabupaten Kutai Barat. (2016). Kabupaten Mahakam Ulu dalam Angka 2015. Kutai Barat: BPS Kabupaten Kutai Barat.

Darlen, M. F., Hadi, S., \& Ardiansyah, M. (2015). Pengembangan Wilayah Berbasis Potensi Unggulan di Kabupaten Manggarai Timur Provinsi NTT Sebagai Daerah Otonom Baru. Jurnal Tata Loka, 17 (1).

Elsheikh, R., Shariff, A.R.B.M., Amiri, F., Ahmad, N. B., Balasundram, S.K., \& Soom, M.A.M. (2013). Agriculture Land Suitability Evaluator (ALSE): A Decision and Planning Support Tool for Tropical Crops. Computer and Computing Technologies in Agriculture, 93, 98-110.

FAO. (1976). A Framework for Land Evaluation. FAO Soil Bulletin No. 32. FAO-UN.

Hardjowigeno, S. \& Widiatmaka. 2007. Evaluasi Kesesuaian Lahan \& Perencanaan Tata Guna Lahan. Yogyakarta: Gajah Mada University Press.

Inglin, F. (2007). Ulu Mahakam: dari Long Iram sampai Long Apari: Riwayatmu Doeloe, Kini, dan Esok. CV Sendawar Ayumas \& PT Banua Ilmu Populer.

Keputusan Presiden Nomor 32 Tahun 1990 tentang Pengelolaan Kawasan Lindung.
Kusumawati, P. (1997). Hubungan Antara Sistem Laaan dan Kesesuaian Lawn Dengan Menggunakan Sistem Informasi Geografi (SIG) Studi Kasus Pengusahaan Tanaman Padi Sawah dan Jagung di Propinsi Jawa Barat. Skripsi. Institut Pertanian Bogor

Nasir, M., Rahmina, \& Fadli, M. Noch. (2009). Gap Analisis Kebijakan Pembangunan Perkebunan Kelapa Sawit Berkelanjutan di Kalimantan Timur. Institut Hukum Sumberdaya Alam \& WWF.

Rahman, R., Baskoro, D.P.T., \& Tjahjono, B. (2015). Prospek Pengembangan Komoditas Perkebunan di Wilayah Boliyohuto Kabupaten Gorontalo. Jurnal Tata Loka, 17 (4).

Rustiadi, E., Saefulhakim, S., \& Panuju, D. R. (2009). Perencanaan dan Pengembangan Wilayah. Bogor: Crestpent Press \& Yayasan Obor Indonesia.

Setiawati, A. R., Sitorus, S.R.P., \& Widiatmaka. (2016). Perencanaan Penggunaan Lahan Komoditas Unggulan Perkebunan di Kabupaten Tanah Datar. Jurnal Tata Loka 18 (3).

Taiyeb, A. (2007). Kajian Kesesuaian Sistem Lahan Salo Saluwan untuk Pembangunan Hutan Tanaman Jati (Tectona grandis L.f.) di Kota Palu, Sulawesi Tengah. Tesis. Universitas Mulawarman.

Widiatmaka. (2013). Analisis Sumberdaya Lahan untuk Perencanaan Tataguna Lahan dan Wilayah. Institut Pertanian Bogor.

Zonneveld, I. S. (1990). Scope and Concepts of Landscape Ecology as an Emerging Science. Changing Landscapes: An Ecological Perspective. Zonneveld, I. S., Foreman, R.R.R., Ed. Berlin: Springer-Verlag. 